\title{
L-аргінін у нормі та патології
}

\section{Л.К. Соколова, В.М. Пушкарьов, М.Д. Тронько}

ДУ «Інститут ендокринології та обміну речовин ім. В.П. Комісаренка НАМН України»

\begin{abstract}
Резюме. L-аргінін - умовно незамінна амінокислота, яка $\epsilon$ клітинним регулятором багатьох життєво важливих функцій організму. Він бере участь у регуляції тонусу гладеньком'язового компонента стінки судин, бронхів, кишечника. L-аргінін є субстратом для синтази оксиду азоту (NOS), яка продукує оксид азоту (NO). NO, що утворюється в ендотелії судин, відповідає за релаксацію гладеньких м'язів і необхідний для зниження артеріального тиску. L-аргінін має високий функціональний пріоритет у продукції NO, а отже, у фізіології серцево-судинної та цереброваскулярної систем. L-аргінін може зменшувати ожиріння, знижувати артеріальний тиск, пригнічувати окислювальні процеси та нормалізувати ендотеліальну дисфункцію, сприяючи ремісії за діабету 2-го типу. L-аргінін також використовується клітинами імунної системи, може знижувати рівень інфікування, надто за порушеня імунної функції. L-аргінін уповільнює старіння, пригнічує агрегацію тромбоцитів, регулює множинні метаболічні шляхи, пов'язані з метаболізмом жирних кислот, глюкози, амінокислот і білків. Тому слід враховувати терапевтичний потенціал L-аргініну та продовжувати вивчення можливостей його використання як перспективного препарату за прогресування судинної дисфункції, пов'язаної зі старінням, діабетом і серцево-судинними захворюваннями.
\end{abstract}

Ключові слова: L-аргінін, оксид азоту, діабет, серцево-судинна система, ожиріння, цереброваскулярна система, імунна система, агрегація тромбоцитів.

\section{Загальні відомості}

L-аргінін (2-аміно-5-гуанідиновалеріанова кислота) - умовно незамінна амінокислота, яка є різнобічним й активним клітинним регулятором багатьох життєво важливих функцій організму. Аргінін є ключовим метаболітом на кінцевому етапі білкового та інших видів обміну азотовмісних сполук, а також відіграє роль незамінного компонента найважливіших регуляторних систем людини та інших ссавців. Без його участі не-

* Адреса для листування (Correspondence): ДУ «Інститут ендокринології та обміну речовин ім. В.П. Комісаренка НАМН України», вул. Вишгородська, 69, м. Київ, 04114, Україна. E-mail: pushkarev.vm@gmail.com

с Л.К. Соколова, В.М. Пушкарьов, М.Д. Тронько можливі системна та локальна регуляція тонусу гладеньком'язового компонента стінки судин, бронхів, кишечника. Аргінін забезпечує ефективність лізосомально-кілінгової системи фагоцитів, бере участь у регуляції проліферативних процесів, функції матриксоутворюючих клітин мезенхімальної лінії [1-3]. Аналіз причин порушення біодоступності аргініну є однією 3 необхідних умов розуміння патогенетичних механізмів розвитку та розробки методів профілактики й лікування найсерйозніших захворювань людини, насамперед атеросклерозу, що є одним з основних чинників, які обмежують тривалість життя. 
Лекції

\section{Джерела аргініну}

L-аргінін є аліфатичною основною $\alpha$-амінокислотою, що містить два основних центри: в $\alpha$-положенні - аміногрупу, в $\delta$-положенні - гуанідинову групу. Існує у вигляді L- i D-ізомерів, але в білках ссавців присутній лише L-аргінін. Найбільше (до 85\%) його міститься в основних білках - протамінах i гістонах. Ha L-аргінін багаті м'ясо та горіхи. L-аргінін - незамінна в новонароджених і замінна в здорових дорослих амінокислота, яку залучено до численних фізіологічних процесів [1-3].

Джерелами надходження аргініну є: 1) синтез у системі тонка кишка - нирки з тонкокишечного глютаміну та глутамату, глютаміну плазми крові, проліну їжі, $\mathrm{NH}_{3}$ i $\mathrm{CO}_{2}$, утворених кишковою мікрофлорою; 2) деградація білків організму; 3) надходження та всмоктування в кишечнику аргініну їжі; 4) локальні механізми ферментативної рециркуляції цитруліну.

У ссавців існує метаболічний шлях для синтезу аргініну. Деякі з ферментів у цьому шляху присутні в багатьох типах клітин, тоді як експресію інших ферментів суттєво обмежено. Фосфат-залежна глутаміназа, орнітинамінотрансфераза (ОАТ), аргінінсукцинатсинтаза (АСС), аргінінсукцинатліаза (АСЛ) та аспартатамінотрансфераза поширені в тканинах тварин, тоді як вміст карбомоїлфосфату I, орнітилкарбомоїлтрансферази (ОСТ) i $\mathrm{N}$-ацетилглутаматсинтази в печінці та слизовій оболонці кишки обмежено. Оксидаза проліну присутня головним чином у тонкій кишці, печінці, нирках, мозку, але синтетазу Р5С локалізовано майже виключно в слизовій кишечника, в інших тканинах вона міститься лише в невеликій кількості. Відмінності в експресії ферментів привели до чіткого поділу метаболічних функцій різних органів [1].

Тонкокишкові глютамін і глутамат, глютамін плазми крові, пролін їжі екстенсивно катаболізуються ентероцитами тонкої кишки та $€$ попередниками синтезу цитруліну. У дорослих цитрулін також синтезується тонкою кишкою $3 \mathrm{NH}_{3}$ і $\mathrm{CO}_{2}$ за участю ферментів орнітинкарбамоїлфосфатсинтетази I, орнітинтранскарбамоїлази і поставляється в нирки та інші тканини для синтезу аргініну. Цитрулін, що надходить із крові, під дією АСС та АСЛ перетворюється в нирках на аргінін. Нирка також експресує аргінази (каталізують гідроліз L-аргініну з утво- ренням орнітину та сечовини), але аргінази та ферменти біосинтезу аргініну локалізовано окремо, в межах різних частин нефрона, так, аби коекспресія цих антагоністичних ферментативних метаболічних шляхів у межах однієї клітини була відсутня або була обмеженою. Синтез аргініну de novo в дорослих становить лише 5-15\% ендогенного пулу, головна складова якого - деградація білків тіла. У здорових дорослих ендогенний синтез аргініну не відіграє головної ролі в регулюванні його гомеостазу. Крім того, ендогенне утворення (de novo і внаслідок деградації білків організму) аргініну забезпечує його достатню кількість без потреби в надходженні ззовні. Але за певних умов, включаючи запалення, дисфункції тонкої кишки або нирок, ендогенний синтез не може забезпечити достатню кількість аргініну, яка відповідала б метаболічним вимогам [1-3]. Для дорослої людини щоденне вживання L-аргініну з їжею в середньому становить 5,4 г [4]. Через високу активність аргіназ до 40\% аргініну, що надходить з їжею, руйнується в процесі абсорбції, а більша його частина надходить у ворітну вену. Залежно від віку та раціону концентрація L-аргініну в плазмі крові людини та тварин коливається в межах від 95 мкмоль/л до 250 мкмоль/л.

\section{Катаболізм аргініну}

Аргінін як субстрат використовується декількома метаболічними шляхами, більшість 3 яких функціонують у межах однієї й тієї ж клітини. Залежно від конкретного органа або типу клітин аргінін $є$ попередником різних молекул, включаючи NO, креатин, сечовину, поліаміни, L-пролін, L-орнітин, глутамат і агматин [1].

Доступність аргініну різним метаболічним шляхам залежить від його здатності проходити крізь плазматичні та мітохондріальні мембрани. Транспорт аргініну крізь клітинну мембрану здійснюється за участю катіонних амінокислотних транспортерів САТ-1/2/3. Основним є CAT-1, активність якого зростає з підвищенням рівня позаклітинного аргініну або під впливом специфічних стимулів. Зміни функції САТ здатні різною мірою обмежувати в клітинах доступність аргініну для індуцибельної синтази оксиду азоту (iNOS) [1].

L-аргінін є субстратом для синтаз оксиду азоту (NOS), які продукують оксид азоту (NO). NO, що утворюється в ендотелії судин ендотеліальною NOS (eNOS), відповідає за релаксацію 
гладеньких м'язів і необхідний для зниження артеріального тиску. L-аргінін також використовується клітинами імунної системи, де NOS продукує NO для клітинного сигналінгу або окислювальних бактерицидних дій [5].

\section{Ендотеліальний оксид азоту / NO-синтетази (NO/NOS)}

Оксид азоту (NO) виконує ключові регуляторні функції, включаючи вазодилятацію та поглинання глюкози. Зниження продукції NO може призвести до клітинної дисфункції, гальмування кровобігу, порушення секреції інсуліну та транспорту глюкози, посилення резистентності до інсуліну та гіпертонії, а також до діабету. Утворення NO пригнічується на тлі серцево-судинних і метаболічних захворювань, викликаючи серйозні порушення [6]. До числа механізмів, що становлять підгрунтя нижчої продукції/доступності NO за метаболічних і серцево-судинних захворювань, можна віднести зниження рівня інсуліну в крові, збільшення вироблення ангіотензину II, гіпергомоцистеїнемію, посилення синтезу асиметричного диметиларгініну (АДМА) та низьку концентрацію L-аргініну в плазмі [7].

Ендотеліальний оксид азоту - важливий вазореактивний чинник [5]. У вільному стані період його напівжиття становить від 6 с до $30 \mathrm{c}$, після чого він швидко руйнується. NO синтезується 3 L-аргініну трьома ізоформами NOS. Вони приєднують молекулярний кисень до атома азоту 3 термінальної гуанідинової групи L-аргініну 3 утворенням NO i L-цитруліну [2, 8]. Три димерних ізоформи NOS кодуються різними генами: нейрональної nNOS (тип 1 NOS, ген NOS1), індуцибельної iNOS (тип 2 NOS, NOS2) і ендотеліальної еNOS (тип 3 NOS, NOS3). Ізоформи nNOS i eNOS є конститутивними. eNOS i ферменти рециркуляції аргініну АCC і АСЛ, катіонні амінокислотні транспортери САТ локалізовано в кавеолярних заглибленнях на ліпідних рафтах плазматичної мембрани ендотеліоцитів, де вони формують функціонально та просторово асоційований ферментний комплекс [1-3].

nNOS i eNOS регулюються транскрипційними, посттранскрипційними (мікроРНК) i посттрансляційними механізмами, включаючи фосфорилювання, ацетилювання, S-нітрозилювання, S-глутатіонілювання та міжбілкові взаємодії. iNOS в основному регулюється за допомогою транскрипції генів в умовах прозапального й окисного стресу. NOS є оксидоредуктазами, гомодимерами, що складаються 3 амінокінцевого оксигеназного домену, який містить сайти зв'язування субстрату - L-аргініну, кофактора тетрагідробіоптерину (BН4), кластера гема, що містить залізо, а також домену редуктази із сайтами зв'язування для донорів електронів: нікотинамід-аденін-динуклеотидфосфату (NADPH), флавін-аденін-динуклеотиду (FAD) і флавін-мононуклеотиду (FMN). Обидва домени сполучено послідовністю, яка зв'язує комплекс кальмодулін- $\mathrm{Ca}^{2+}$. За активації NOS флавіни в редуктазному домені переносять отримані від NADPH електрони на гем в оксигеназному домені іншого мономера, забезпечуючи зв'язування кисню $\left(\mathrm{O}_{2}\right)$ з відновленим залізом гема $\left(\mathrm{Fe}^{2+}\right)$ і перетворення L-аргініну на HO-L-аргінін, а потім на NO та L-цитрулін [9]. Кофакторами активації eNOS виступають протопорфірин-IX, BH4, FMN, FAD та іони $\mathrm{Zn}^{2+}$, що тетраїдально зв'язують мономери через цистеїнові залишки. eNOS - основна ізоформа NOS у нормальній судинній стінці [10]. Рекрутування комплексу $\mathrm{Ca}^{2+}$-кальмодулін необхідно для перенесення електронів. Значне збільшення внутрішньоклітинної концентрації $\mathrm{Ca}^{2+}$ необхідно, аби цей комплекс зв'язував eNOS i nNOS, тоді як зв'язування iNOS відбувається за базальних концентрацій $\mathrm{Ca}^{2+}$. ВН4, зв'язаний із димерами NOS, необхідний для їх стабілізації та належної каталітичної активності. В іншому випадку електрони переносяться безпосередньо на $\mathrm{O}_{2}$, $\mathrm{i}$ замість NO виробляються супероксидні аніони $\left(\mathrm{O}^{2-}\right)$. Субклітинна локалізація NOS визначає синтез NO у компартментах і передачу сигналів по регуляторному ланцюгу специфічним ефекторам [9].

eNOS - найважливіша синтаза - синтезується як гомодимер, який транспортується до клітинної мембрани в місця утворення нею особливих інвагінацій - кавеол, де депонується у функціонально неактивному стані, зв'язуючись із кавеоліном-1 - головним білком, відповідальним за формування та підтримку форми кавеол [10]. Синтез NO вимагає точного співвідношення субстрату та кофакторів. Напруга зсуву, викликана в'язкою природою кровобігу, що тягнеться вздовж судинної стінки, активує eNOS шляхом фосфорилювання різними протеїнкіназами. Akt фосфорилює eNOS по Ser1177, iii основному сайту активації, а інгібуючий за- 
Лекції

лишок Thr495 дефосфорилюється фосфатазами РP1, РP2А та кальциневрином (РP2B) [9]. Активований фермент потім транслокується в цитозоль. Фосфорилювати eNOS по Ser1177 можуть інші кінази, включаючи АМРК, кальцій/кальмодулін-залежну протеїнкіназу II типу та протеїнкіназу А. Фосфорилювання Ser615 або Ser633 (кіназами Akt, AMPK, PKA або Pim-1) [11] i Tyr81 тирозинкіназою Src також пов'язано зі збільшенням продукції NO. I навпаки, фосфорилювання по Ser114 кіназами ERK1/2, протеїнкіназою C і Tyr657 тирозинкіназою $2 \beta$ (РYК2) знижує синтез NO [9, 12].

NO дифундує в клітини гладенької мускулатури судин, активує гуанілатциклазу й індукує опосередковану сGMP (циклічний гуанозин 3',5'-монофосфат) релаксацію гладеньких м'язів шляхом активації сGMP-залежної протеїнкінази G (PKG) і подальшого фосфорилювання білків калієвих каналів, зниження рівня кальцію в цитозолі та дефосфорилювання легкого ланцюга міозину [4, 8]. У кінцевому підсумку це регулює регіональний кровобіг (тобто потік-опосередковану дилятацію). Інші субстрати та кофактори, необхідні для цієї реакції, включають кисень, NADPH, флавін, гем i BH4 [4]. Останній зв'язується з гем-групою $\mathrm{N}$-кінцевого оксидазного домену NOS, стабілізуючи димерну молекулу. Зв'язування переводить NOS у високий спіновий стан, збільшує активність ферменту та посилює спорідненість NOS до аргініну [13]. У нормальних умовах eNOS у присутності достатньої кількості BН4 приймає та зберігає електрони з NADPH для перетворення косубстратів $\mathrm{O}_{2}$ i L-аргініну на NO та L-цитрулін [14]. BH4 приймає електрони від флавіну в С-кінцевій редуктазній ділянці NOS під час синтезу NO та L-цитруліну, діючи як важливий окислювально-відновний агент. Дисфункція на будь-якій із цих стадій, наприклад у процесі старіння, може призвести до порушення реакції, зниження біодоступності NO, ослаблення вазодилятації і змін у регіональній циркуляції та перфузії тканин [13].

$\mathrm{NO}$, синтезований eNOS, виконує цілу низку функцій: 1) є одним із найпотужних вазодилататорів, релаксуючим чинником для гастроінтестинального тракту, дихальних шляхів - проникаючи з ендотеліальних клітин у клітини гладеньких м’язів судинної стінки, він активує розчинну гуанілатциклазу, взаємодіючи 3 ато- мом заліза в активному центрі ферменту, що веде до підвищення рівня сGMP, активації PKG, зниження концентрації кальцію, розслаблення судин [10, 15]; 2) опосередковує судинорозширювальні ефекти ендотелій-залежних вазодилататорів (ацетилхоліну, брадикініну, гістаміну тощо), гальмує утворення ендотеліального судинозвужувального чинника - ендотеліну-1 i вивільнення норадреналіну закінченнями симпатичних нейронів, перешкоджає здійсненню надмірних ефектів інших вазоконстрикторів (ангіотензину, тромбоксану А2); завдяки цьому NO бере активну участь у регуляції судинного тонусу та кровобігу (в тому числі базального), артеріального тиску, системної та регіональної гемодинаміки [15]; 3) стимулює синтез ендотеліального чинника росту й ангіогенез, але гальмує проліферацію та міграцію гладеньком'язових клітин (тим самим перешкоджаючи утворенню неоінтими) і гіпертрофію судин $[4,8]$; 4) у невеликих концентраціях гальмує, а у високих - посилює апоптоз, пригнічує синтез позаклітинного матриксу, чим підтримує нормальну структуру судинної стінки $[4,8] ; 5)$ чинить потужну протизапальну та антитромбогенну дію: гальмує транскрипцію прозапального ядерного чинника каппа B (NF-кB), блокує стимульовану цитокінами експресію адгезійних молекул ендотелію (VCAM-I, Е-селектин, MCP) і хемотаксичних пептидів моноцитів, зменшує прилипання, інфільтрацію, агрегацію нейтрофілів і моноцитів, перетворення останніх на макрофаги, гальмує агрегацію й адгезію тромбоцитів, експресію чинника, що активує тромбоцити; 6) має антиоксидантні властивості, перешкоджає патогенним впливам ліпопротеїнів низької щільності $[4,11]$; 7) NO/NOS беруть участь в опосередкованій РКС регуляції альдостерону іонами калію, що пов'язано з підтриманням водно-сольового балансу та тонусу судин в організмі [16].

\section{Роль аргініну в патологічних процесах}

Основним наслідком нестачі аргініну в організмі є зниження продукції NO. NO, що продукується в ендотелії судин еNOS, відповідає за релаксацію гладеньких м'язів і необхідний для зниження артеріального тиску. Будь-яке поліпшення функції ендотелію сприяє профілактиці серцево-судинних захворювань (CC3). Показано, що введення L-аргініну значно зменшує систолічний і діастолічний артеріальний тиск, але у вагітних жінок знижувався 
лише діастолічний артеріальний тиск. Добавка L-аргініну також значно поліпшувала функцію ендотелію судин. Важливим є вплив аргініну на імунну систему. Пацієнти, які отримували внутрішньовенну терапію L-аргініном, демонстрували значне збільшення кількості CD4+ лімфоцитів (Т-хелперів) [2, 3].

L-аргінін ісерцево-судинна система. У фізіологіїтапатофізіологіїСССефектNOєключовим в ендотелій-залежній дилятації судин [2,3] - рис. Показано, що інгібування NOS i, отже, зниження продукції NO викликає гіпертонію та гіпертрофію серця, призводить до розвитку атеросклерозу. L-аргінін є єдиним попередником синтезу $\mathrm{NO}$, а його катаболічні ферменти, які справляють найбільший вплив на CCC, - це NOS та аргіназа $[2,3,17]$. L-аргінін є субстратом для NOS, яка перетворює його на L-цитрулін із вивільненням NO. Iз цитруліну L-аргінін може бути відновлений ферментами АСС та АСЛ $[2,3]$, але може руйнуватися аргіназами. Зниження біодоступності NO внаслідок зменшення продукції NOS або утворення активних форм кисню (ROS) пов'язано з розвитком різних судинних порушень [18], включаючи вазоконстрикцію, агрегацію тромбоцитів та утворення тромбу, адгезію лейкоцитів, проліферацію та міграцію гладеньком'язових клітин судин (VSMC) [19]. Крім того, ендотеліальну дисфункцію (ЕД), що виникає на ранніх стадіях розвитку атеросклерозу, також пов'язано з порушенням біодоступності NO [19, 20]. Біологічну активність NO пригнічують численні чинники, такі як зниження поглинання L-аргініну, зменшення вмісту кофакторів NOS ( $\mathrm{Ca}^{2+}$, кальмодулін, BH4), пригнічення потоку електронів (NADPH, флавін), пригнічення експресії NOS [18, 19].

Короткочасне та хронічне введення L-аргініну поліпшувало функцію ендотелію на тваринних моделях гіперхолестеринемії та атеросклерозу [21]. Підвищення його концентрації в плазмі приводить до збільшення продукції як судинного, так і системного NO. Дослідження VSMC показали, що обмежувальним чинником для посилення синтезу NO за допомогою iNOS є можливість рециклінгу L-аргініну $[2,3]$. Показано, що активність iNOS залежить від концентрації позаклітинного L-аргініну. Можливість існування внутрішньоклітинного пулу L-аргініну, недоступного для iNOS, унаслідок чого позаклітинний аргінін необхідний для активності iNOS і продукції NO, отримало назву «парадоксу L-аргініну» та належить до конкретної ситуації, коли добавка L-аргініну стимулює активність NOS і вироблення NO, навіть якщо рівень L-аргініну в плазмі знаходиться у фізіологічних межах [18].

Ендокринні механізми також можуть сприяти вазодилятації, викликаної L-аргініном. Високі внутрішньовенні дози L-аргініну стимулюють секрецію гормону росту (GH). GH та інсулін, вивільнення якого також стимулюється L-аргініном, можуть викликати вазодилятацію [18].

Внутрішньовенна інфузія L-аргініну або D-аргініну викликала вазодилятацію. Це дозволяє припустити, що такий ефект пов'язаний з осмоляльністью або $\mathrm{pH}$, а не лише з посиленням утворення ендотеліального NO. Вазодилятація була значною тільки за високих концентрацій L-аргініну в плазмі - від мікро- до мілімолярних [22].

Системне або пероральне введення L-аргініну поліпшує серцево-судинну функцію та зменшує ішемію серця в пацієнтів, які мають захворювання коронарних артерій, а також приводить до зниження артеріального тиску та судинного опору в нирках у пацієнтів із гіпертонічною хворобою і нормальною або порушеною функцією нирок. Хоча концентрація L-аргініну в плазмі в пацієнтів із гіперхолестеринемією залишається незмінною, пероральне або внутрішньовенне введення L-аргініну може відновити ендотеліальну функцію в них.

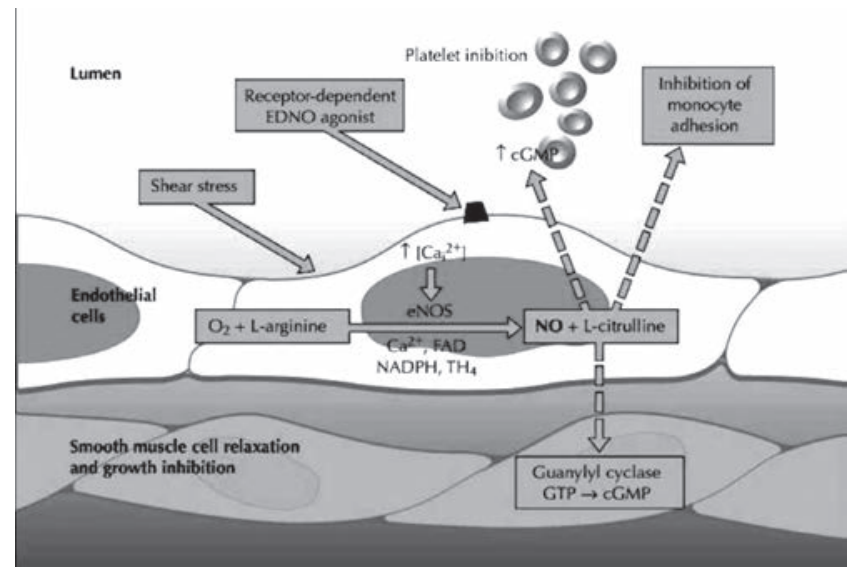

Рис. Схема дії аргініну та NO в стінці кровоносної судини (beloveshkin.com): в ендотелії eNOS окисляє аргінін до NO та цитруліну; NO протидіє запальному процесу (в даному випадку викликаного напругою зсуву), пригнічуючи адгезію моноцитів, формування тромбу та релаксуючи шар гладеньком'язової мускулатури, що лежить нижче. 
Лекції

Існує думка, що атеросклероз викликано нестачею L-аргініну, найімовірніше, через порушені: взаємозв'язок між лізином і L-аргініном i взаємодію між метаболізмом естрогену та L-аргініну [18]. L-аргінін бере участь у профілактиці атеросклерозу й ефективно знижує негативний вплив вже присутніх атеросклеротичних змін. Так, він уповільнює адгезію моноцитів до ендотелію, знижує артеріальний тиск у деяких пацієнтів із гіпертонією та повертає ендотеліальну функцію до норми в пацієнтів із гіперхолестеринемією.

Отже, L-аргінін має високий функціональний пріоритет у продукції NO, а отже, у фізіології ССС. Регуляція біодоступності NO після застосування препаратів L-аргініну має вирішальне значення для розробки нових стратегій лікування CC3. L-аргінін є одним із можливих терапевтичних засобів для корекції різних серцево-судинних порушень.

L-аргінін $і$ цереброваскулярная система. Фенотипи ендотеліальних клітин по-різному регулюються в просторі та часі, визначаючи феномен гетерогенності ендотелію. Церебральний ендотелій, імовірно, є одним із найбільш специфічних типів, оскільки він є найважливішим елементом гематоенцефалічного бар’єру. ЕД головного мозку бере участь у патофізіології низки неврологічних захворювань [23].

На додаток до атеросклерозу, дисфункція ендотелію системи мозкового кровообігу може бути залученою до патогенезу церебральних захворювань дрібних судин і хвороби Альцгеймера. Порушення NO-залежної вазодилятації може також збільшити ділянку пошкодження під час інсульту через порушення колатерального кровобігу [24]. Церебральна авторегуляція підтримує постійний кровобіг (CBF) через мозок попри зміни середнього артеріального тиску та залежить, принаймні частково, від змін локальної концентрації L-аргініну в мозку та швидкості його метаболізму [25]. Авторегуляція мозкового кровобігу складається 3 механо- та хеморегуляції. Хеморегуляція прямо корелює із сироватковим рівнем $\mathrm{CO}_{2} \mathrm{i}$, на відміну від механорегуляції, не залежить від змін середнього артеріального тиску. Механорегуляція залежить від трансмурального градієнта тиску й ендотеліальної вазодилятації. Механорегуляція є основним контролюючим механізмом CBF. Відомо, що ендотеліальна вазодилятація великих арте- рій найбільше виражена в судинній мережі головного мозку [23]. Нормальна функція ендотелію має вирішальне значення для регуляції CBF. Дисфункціональний церебральний ендотелій виділяє менше NO, внаслідок чого порушується розслаблення клітин гладеньких м'язів дрібних артерій. Найважливішою роллю L-аргініну $\mathrm{\epsilon}$ його вплив на ендотеліальні клітини судин мозку, а отже, на кровобіг. Внутрішньовенне введення L-аргініну викликає розширення судин та збільшення кровобігу в системі мікроциркуляції. До того ж показано, що L-аргінін відіграє роль у зниженні тромботичної активності, проліферації клітин, запалення та інших процесів, які призводять до порушень судинної системи мозку.

Доведено, що використання L-аргініну є безпечним. NO відомий як найефективніший вазодилятатор та основний предиктор судинного тонусу в цереброваскулярній системі [26]. Із трьох ізоформ NOS саме eNOS є основою NO-опосередкованої вазодилятації мозкових артерій та артеріол [23]. Показано, що eNOS-залежне продукування NO в ендотелії мозку знижує активність симпатичної нервової системи й артеріальний тиск у щурів. Аналогічно надекспресія eNOS у ростральній вентролатеральній частині довгастого мозку й ядрах солітарного тракту зменшує артеріальний тиск та активність симпатичного нерва. Нові дані, отримані від прямого виміру симпатичної нервової активності 3 використанням імплантованих електродів, вказують, що екзогенний NO може зменшити вплив симпатичної нервової системи на серце [27, 28]. Є також дані, що зниження біодоступності NO в паравентрикулярному ядрі посилює розрядку ниркового симпатичного нерва. Зниження рівнів NO може збільшити симпатичний вплив на нирку через посилення специфічного пригнічення eNOS-залежного продукування NO в паравентрикулярному ядрі гіпоталамуса, що підвищує реакцію ниркового симпатичного нерва (RSNA). Пригнічення NOS шляхом внутрішньовенного введення NG-метил-1-аргініну також збільшує RSNA [29].

Церебральна ендотеліальна функція може бути різною на різних цереброваскулярних ділянках. Крім того, деякі ділянки мозку можуть бути більш схильними до ішемії та інсульту. Відзначено більші частоту та поширеність інсульту серед чоловіків. Визначення 
цереброваскулярної реактивності на L-аргінін (CVR-L-Arg) є унікальним, недорогим, багатообіцяючим неінвазійним методом обстеження, який може надати засоби для оцінки функції ендотелію головного мозку у фізіологічних і патологічних станах. Порівняння CVR-L-Arg у кровообігу передньої та задньої частин мозку в здорових молодих чоловіків і жінок показало, що CVR-L-Arg була значно вищою в задній мозковій артерії (РСА), ніж у середній мозковій артерії (MCA). Крім того, CVR-LArg була більш вираженою в жінок, ніж у чоловіків, у PCA та MCA. Нижча CVR-L-Arg (а отже, й нижча ендотеліальна функція головного мозку) в кровообігу передньої частини мозку в чоловіків можуть пояснювати більшу частоту ішемії й інсультів у них [23].

Цереброваскулярна дисфункція, викликана екзогенними стресовими чинниками, включає внутрішньочерепну гіпертензію, гіпоперфузію та запалення головного мозку. Лікування L-аргініном одразу після стресу значно поліпшувало виживання тварин, зменшувало внутрішньочерепну гіпертензію та збільшувало вміст метаболітів NO, глутамату, гліцерину, лактат-пірувату та дигідроксибензойної кислоти в гіпоталамусі. Зумовлені екзогенними чинниками підвищені рівні прозапальних IL-1 $\beta$ i TNF- $\alpha$ в гіпоталамусі також знижувалися на тлі лікування L-аргініном. Навпаки, рівні протизапального IL-10 у гіпоталамусі значно підвищувалися. Результати показують, що L-аргінін може ослаблювати негативний вплив екзогенних стресових чинників за рахунок зниження цереброваскулярної дисфункції та запалення мозку [30].

$\boldsymbol{L}$-аргінін $\boldsymbol{i}$ діабет. Діабет 2-го типу (ЦД2) став глобальною проблемою охорони здоров'я, яка зачіпає близько 425 мільйонів людей у всьому світі. Це в перспективі може викликати безліч ускладнень і призвести до більшої смертності. Наразі немає доступних ліків для ефективної профілактики діабету. L-аргінін як попередник NO відіграє важливу роль у гомеостазі, імунітеті, розмноженні, рості, затримці старіння людини та тварин. Дедалі більше клінічних даних свідчать, що харчові добавки з L-аргініном можуть зменшувати ожиріння, знижувати артеріальний тиск, окислювальні процеси, ЕД, сповільнюючи прогресування переддіабету в клінічно виражений
ЦД2. Потенційним молекулярним механізмом може бути модулювання гомеостазу глюкози, стимулювання ліполізу, підтримання рівнів гормонів, ослаблення інсулінорезистентності на етапі переддіабету. Можливий сигналінг дії L-аргініну, ймовірно, включає в себе шлях L-аргінін/NO, через який можуть бути активовані інші клітинні сигнальні каскади [31]. Накопичені дані показали, що L-аргінін може потенційно запобігати розвитку та полегшувати перебіг ЦД2 шляхом відновлення чутливості до інсуліну.

Слід зазначити, що за ЦД2 вміст антагоніста L-аргініну - ADMA (асиметричний диметиларгінін - ендогенний чинник, що пригнічує синтез NO) збільшувався в плазмі у 2,5 рази, що було пов'язано зі зниженням NO-залежної функції - вазодилятації плечової артерії після індукованої ішемією гіперемії [32]. Кількість ADMA в плазмі збільшувалася й у відповідь на приймання їжі з високим вмістом жиру, що також було пов'язано зі зменшенням ступеня вазодилятації. Ці зміни асоціювалися з підвищенням рівня тригліцеридів у плазмі крові та тригліцеридів, що входять до складу ліпопротеїнів дуже низької щільності. Зростання вмісту ADMA за діабету супроводжувалося порушенням ендотелій-залежної релаксації та поганим метаболічним контролем. Підвищена концентрація ADMA може викликати пов'язану з діабетом ЕД і макроангіопатії. Цікаво відзначити, що інгібітори ангіотензинперетворюючого ферменту, але не глітазони, знижували рівні ADMA в плазмі за ЦД2 попри те, що глітазони поліпшували функцію ендотелію та зменшували експресію маркерів запалення [33].

Ендотеліальні клітини виробляють NO вазодилятатор та антиагрегатний чинник тромбоцитів, концентрація якого знижується в пацієнтів із гіпертонією та ЦД2. Дієти, збагачені вуглеводами та насиченими жирами, зменшують утворення NO, викликають ЕД і підвищують опір периферичних судин. Рівні ADMA в крові підвищено в пацієнтів з ожирінням, дисліпідемією, гіпертонією, ЦД2, гестаційним ЦД і прееклампсією. Підвищення кількості ADMA в крові, мабуть, передує розвитку гіпертонії та ЦД2. Рівні ADMA в крові корелювали 3 неконтрольованою гіперглікемією, діабетичними мікро- та макроангіопатіями. Добавка L-аргініну знижує ЕД і відновлює нормальний 
Лекції

опір периферичних судин за рахунок зниження рівня ADMA в крові та посилення продукції NO [33].

L-аргінін стимулює секрецію різних гормонів, включаючи GH, інсулін, глюкагон, адреналін, норадреналін і пролактин [34]. Інсулін, у свою чергу, стимулює експресію САТ-1 і транспорт L-аргініну в ендотеліальні клітини. Тому у хворих на діабет знижується вміст L-аргініну та NO в клітинах судин [35]. Тривале пероральне введення L-аргініну підвищує чутливість до інсуліну та метаболізм глюкози з одночасним поліпшенням функції ендотелію в пацієнтів із ЦД2 [36]. L-аргінін (6,4 г/добу) значно збільшує регресію до нормальної толерантності до глюкози, підвищуючи чутливість до інсуліну в пацієнтів, а також у деяких моделях діабету та в щурів з ожирінням [37]. Здатність L-аргініну послаблювати ефекти метилгліоксалю, реактивного метаболіту глюкози та попередника кінцевих продуктів глікування (AGE), може становити підгрунтя позитивних ефектів приймання L-аргініну в людей із діабетом [38]. Як $\mathrm{D}$-аргінін, так і L-аргінін можуть послаблювати експресію аргіназ I і II, окислювальний стрес, ЕД та утворення AGE, викликане метилгліоксалем і високим вмістом глюкози. L-аргінін може запобігати індукованій метилгліоксалем дисфункції $\beta$-клітин підшлункової залози, а також знижувати поглинання глюкози жировою тканиною [38], що потенційно пояснює підвищення чутливості до інсуліну [36, 38].

Показано, що пероральне приймання L-аргініну може посилювати транскрипцію гуанозинтрифосфатциклогідролази I, першого ферменту в синтезі ВН4 de novo, збільшуючи утворення BH4 і NO, а також знижуючи рівень глюкози в плазмі за діабету 1-го типу в щурів. BH4, один із найсильніших антиоксидантів у клітині, відіграє вирішальну роль не лише в збільшенні швидкості синтезу NO за допомогою eNOS, а й у зменшенні утворення $\mathrm{O}_{2}-$ в ендотеліальних клітинах. Підвищення рівня як субстрату eNOS, L-аргініну, так і їі критичного кофактора, BН4, є необхідним для забезпечення адекватного синтезу NO в ендотелії [36].

L-аргінін та ожиріння. Ожиріння пов'язано зі зниженням транспорту L-аргініну навіть за відсутності метаболічного синдрому [39]. Поширеним наслідком ожиріння є гіпертензія, яка спостерігається за ожиріння приблизно в 75\% і 65\% випадків у чоловіків і жінок відповідно. Часто суб'єкти з ожирінням $€$ стійкими до стандартних антигіпертензивних препаратів, а погане розуміння точних механізмів, що становлять підгрунтя зв'язку між ожирінням і гіпертонією, перешкоджає розвитку нової та ефективної терапії. Виявлено, що ожиріння пов'язано зі зменшенням біодоступності NO, викликаної порушенням транспорту L-аргініну, та що посилення перенесення ендотеліального аргініну запобігає експериментальній гіпертензії, викликаній ожирінням [40]. Результати інших досліджень також дають чіткі докази, що ЕД відіграє важливу роль у патогенезі гіпертонії, пов'язаної з ожирінням [40]. Добавка L-аргініну значно поліпшувала ендотеліальну функцію судин. Для пацієнтів із гіпертонічною хворобою використання L-аргініну помітно знижувало як систолічний, так і діастолічний артеріальний тиск. Ці дані отримано в понад 600000 учасників, тому можна стверджувати, що помірні зміни в артеріальному тиску є клінічно значущими, оскільки зниження систолічного артеріального тиску на 5 мм рт. ст. пов'язано зі зниженням ризику інсульту на $14 \%$ і на $9 \%$ - ризику ішемічної хвороби серця $[5,41]$.

Добре відомо, що NO знижує окислювальний стрес, і показано, що зниження рівня NO разом із посиленням окислювального стресу може провокувати розвиток гіпертонічної хвороби, асоційованої з ожирінням [42]. Посилення специфічного для ендотелію транспорту аргініну може запобігти окислювальному стресу на додаток до збільшення біодоступності NO [28].

Хронічна активація ренін-ангіотензин-альдостеронової системи (РААС) є відмінною рисою гіпертонії, пов'язаної з ожирінням [43]. У розвитку гіпертонії задіяно як нирковий, так i нейрогенний механізми [23]. Зокрема, посилений симпатичний відтік, хронічна активація РААС, окислювальний стрес і зниження доступності NO, надто в нирках, можуть бути ланками патогенезу гіпертонічної хвороби, пов'язаної з ожирінням. Порушення транспорту L-аргініну за ожиріння може знизити біодоступність NO і тим самим посилити окислювальний стрес і симпатичний відтік, викликати активацію РАAC і посилити наступні прогіпертензивні ефекти симпатичної нервової 
системи та РААС - порочне коло, що веде до гіпертонії. За ожиріння L-аргінін/NO можуть пом'якшити ефекти РАAC через 2 механізми: по-перше, NO може знизити активацію РАAC, i, по-друге, NO може буферизувати індуковану ангіотензином II периферичну вазоконстрикцію. Відповідно, стратегії лікування, які збільшують вміст L-аргініну й утворення NO, ймовірно, будуть корисними за гіпертонії, пов’язаної з ожирінням [28].

Дедалі більше даних свідчать, що приймання аргініну ефективно зменшує кількість білої жирової тканини в щурів з ожирінням і в пацієнтів з ожирінням та ЦД2. Отже, аргінін можна використовувати для профілактики й лікування ожиріння та пов'язаного з ним метаболічного синдрому.

L-аргінін $i$ діабетична нейропатія. Діабетична нейропатія (ДН) є характерним, поширеним, незворотним на пізніх стадіях ускладненням ЦД1 і ЦД2 [44]. ДН мають 30\% госпіталізованих і $20 \%$ осіб, які не є госпіталізованими $з$ діабетом. Вона може проявлятися навіть в осіб з аномальною толерантністю до глюкози, що є переддіабетичним станом [45]. ДН є найпоширенішою формою нейропатій у розвинених країнах і провідною причиною нетравматичних ампутацій [46].

У патогенезі ДН задіяно декілька сигнальних каскадів, в яких беруть участь циклооксигеназа-2 та оксид азоту [46]. Патофізіологія ДН включає: посилення окислювального стресу, що спричиняє утворення кінцевих продуктів глікування (AGE), накопичення поліолів, гальмування ефектів NO та порушення функції ендотелію, пригнічення активності $\mathrm{Na}^{+} / \mathrm{K}^{+}$АТФази та гомоцистеїнемію. У гіперглікемічному середовищі не лише швидше руйнуються нервові клітини, але й порушуються механізми їх відновлення. За експериментального діабету також відзначається знижений рівень нейротропних агентів, включаючи нервовий та інсуліноподібний чинники росту [45].

Судинні чинники також беруть участь у патогенезі ДН. Нервовий кровобіг зменшується за експериментальної діабетичної нейропатії, і численні дослідження свідчать, що це може бути опосередковано змінами в метаболізмі NO. Вивчення нервового кровобігу та активності NOS у мікросудинному середовищі, що «обслуговує» периферичні нерви в діабетичних щурів, показало, що гіперглікемія та N-нітро-L-аргінін, інгібітор NOS, провокували значне послаблення нервового кровобігу порівняно з контролем. L-аргінін знімав гальмування NOS і відновлював приплив крові до нервів [45].

Дослідження на тваринах також виявило порушення функціонування нейрональної синтази оксиду азоту (nNOS) за експериментального діабету. Зниження експресії nNOS було пов'язано з посиленням нейропатичного болю. NO відіграє важливу роль у контролі $\mathrm{Na}^{+} / \mathrm{K}^{+}$-АТФазної активності, зниження якої пов'язано з патогенезом ДН. Показано, що внаслідок гіперглікемії утворюється надлишок радикалів супероксиду в ендотелії, що призводить до зниження стимуляції $\mathrm{NO} \mathrm{Na}^{+} / \mathrm{K}^{+}$АТФазної активності. Цей ефект гальмується L-аргініном [45].

Результати досліджень вказують на профілактичний ефект L-аргініну, що спостерігався в діабетичних щурів як на рівні поведінки, так i на рівні гістології. На молекулярному рівні аргінін пригнічував спинномозкову міРНК-155 та їі мішень, що знаходиться нижче в регуляторному ланцюгу - NO [46].

Показано, що L-аргінін запобігає механічній гіпералгезії, тактильній і термічній алодинії в щурів з індукованим стрептозотоцином діабетом і нейропатією шляхом нормалізації концентрації NO та підвищення концентрації агматину в плазмі крові. Пероральне введення L-аргініну також зменшувало полідипсію, поліурію, виділення азоту із сечею та незначно обмежувало гіпоінсулінемію [44].

Отже, за ЦД приймання аргініну може бути оригінальною терапевтичною альтернативою без серйозних побічних ефектів для запобігання виникненню нейропатичного болю. Отримані дані підкреслюють терапевтичні мішені та визначають профілактичний підхід до лікування ДН.

L-аргінін і старіння. У літніх людей периферичний опір судин зростає, і артерії втрачають здатність до ефективної дилятації через ЕД. Ця судинна сенесценція зумовлює збільшення ризику СС3 у процесі старіння [4]. Останнім часом значна увага приділяється здатності L-аргініну впливати на функцію ендотелію судин. Із віком виникає поширена дисфункція судин, яка проявляється в ослабленні 
Лекції

дилятаторної здатності периферичних судин, зумовленому ЕД. Ендотелій судин є одноклітинним шаром, відповідальним за численні автокринні, паракринні й ендокринні функції, включаючи регуляцію судинного тонусу, запалення судин, клітинний ріст, тромбоз і функції тромбоцитів. NO, потужний вазоактивний чинник, що вивільняється ендотеліальними клітинами у відповідь на напругу зсуву, відіграє ключову роль у підтримці судинної стінки в спокійному стані за допомогою пригнічення запалення, клітинної проліферації та тромбозу $[47,48]$. ЕД, пов'язана зі старінням, може бути результатом зниження як утворення NO, так і його біодоступності. Втрата NO сприяє переходу судинної стінки від спокійного стану до активованого. Експресія клітинами судин хемокінів, цитокінів і молекул адгезії збільшується, що призводить до залучення лейкоцитів, агрегації тромбоцитів та ініціації атеросклеротичного процесу. ЕД розвивається на ранніх стадіях атерогенного процесу та є основним чинником розвитку будь-яких морфологічних атеросклеротичних змін [4, 47].

Напруга зсуву активує eNOS за допомогою фосфорилювання. NO дифундує в клітини гладенької мускулатури судин та індукує релаксацію гладеньких м'язів [8], що регулює регіональний кровобіг. У процесі старіння може знижуватися доступність NO, ослаблюватися вазодилятація та змінюватися регіональна циркуляція і перфузія тканин [4]. Зменшення кількості аргініну може обмежувати швидкість утворення NO, а згодом і ендотелій-залежну вазодилятацію. Наразі вивчається можливість використання L-аргініну як профілактичного засобу для захисту судинної мережі від руйнівних наслідків старіння та хвороб [4].

На відібраних популяціях пацієнтів похилого та старечого віку з ЕД і зменшеними запасами L-аргініну показано, що додавання останнього до комплексної терапії може поліпшувати судинну функцію за рахунок збільшення вмісту NO. L-аргінін може також відновити функцію ендотелію за допомогою допоміжних ефектів щодо системної гормональної модуляції (GH) і протизапальних/антиоксидантних змін в ендотеліальних клітинах [4].

Вплив аргініну на агрегацію тромбоциmiв. Виявлено виражене пригнічення агрегації тромбоцитів, індукованої аденозин-5'- дифосфатом (ADP), колагеном або тромбіном, як після перорального, так і після iv введення L-аргініну кролям. На кролях із гіперхолестеринемією також показано, що тривале введення цієї амінокислоти значно пригнічує індуковану ADP-агрегацію тромбоцитів. Подібні дані отримано й на щурах з алоксановим діабетом і на свинях. Отже, результати досліджень на тваринних моделях ясно показують гальмівну роль L-аргініну щодо активності тромбоцитів [49, 50].

Клінічні дослідження також свідчать про вплив L-аргініну на агрегацію тромбоцитів. Після введення L-аргініну протягом 7 днів для лікування периферичних артеріальних обструктивних захворювань спостерігали пригнічення спонтанної, колаген- і ADP-індукованої агрегації тромбоцитів. Терапія цією амінокислотою знижувала здатність тромбоцитів до агрегації в пацієнтів із гіперхолестеринемією, ЦД2 та артеріальною гіпертензією. Відзначено нормалізацію колаген-індукованої агрегації в пацієнтів із підвищеним рівнем холестерину після перорального введення L-аргініну. Його позитивний ефект спостерігався також щодо гострої коронарної недостатності. Препарат поліпшував ендотеліальну функцію та пригнічував ADP-індуковану агрегацію тромбоцитів [49].

Отже, отримані результати показують, що L-аргінін може модифікувати гемостаз шляхом пригнічення коагуляції й активації фібринолізу.

Інші ефекти L-араініну. L-аргінін регулює множинні метаболічні шляхи, пов'язані з метаболізмом жирних кислот, глюкози, амінокислот і білків за допомогою передачі сигналів у клітинах і контролю експресії генів. Крім того, аргінін регулює перехресні взаємодії між адипоцитами та м'язами і розподіл енергії через секрецію цитокінів та гормонів. Аргінін підсилює експресію й активність АМР-активованої протеїнкінази (АМРК), тим самим модулюючи енергетичний баланс і ліпідний обмін у бік зменшення кількості триацилгліцеридів [51].

Зараз аргінін визнаний фізіологічно важливою поживною речовиною для підтримки репродуктивної функції в чоловіків і жінок [51].

L-аргінін також використовується клітинами імунної системи та може допомогти знизити рівень інфікування, надто в ситуаціях, 
пов'язаних із порушенням імунної функції, таких як хірургічне втручання або серйозне захворювання [52]. Для хірургічних або лікарняних пацієнтів показано, що L-аргінін значно (на 40\%) зменшує можливість зараження лікарняною інфекцією та виникнення інфекційних ускладнень, включаючи пневмонію, абсцес черевної порожнини, септичний шок, фасціїт та інфекції сечостатевого тракту. Імунні клітини використовують L-аргінін для продукування NO (через iNOS) для посилення клітинної імунної функції шляхом модуляції утворення цитокінів, а також проліферації та диференціювання лімфоцитів. У пацієнтів, які приймали препарати аргініну, кількість CD4+ T-клітин значно збільшувалася [5].

Останнім часом велика увага приділяється впливу порушень метаболізму L-аргініну на канцерогенез та імунну систему. L-аргінін необхідний для дозрівання дзета-рецептора T-клітин (TCR ), а його відсутність позбавляє Т-клітини здатності взаємодіяти з пухлинними антигенами. У мієлоїдних клітинах-супреcopax вміст L-аргініну виснажується через високий рівень експресії аргіназ, а їх кількість збільшується в 4-10 разів залежно від типу раку. Показано, що L-аргінін необхідний для виживання та прогресії аргінін-ауксотрофних пухлин. Проте прогресія неауксотрофних щодо аргініну пухлин не залежить від екзогенного L-аргініну, оскільки ці пухлини мають активність ACC1 і здатні продукувати L-аргінін із цитруліну. Клінічні дослідження підтвердили високу ефективність терапії ауксотрофних за аргініном пухлин, заснованої на елімінації L-аргініну. Додавання L-аргініну може поліпшити результати лікування пацієнтів із неауксотрофним за аргініном раком [53].

L-аргінін впливає на синтез білка та прискорює загоєння ран, посилюючи синтез проліну, що важливо для утворення колагену, а також синтез поліамінів, які сприяють росту клітин, проліферації та диференціюванню [54]. Як зазначалося, L-аргінін стимулює секрецію декількох анаболічних гормонів, таких як інсулін, гормон росту та інсуліноподібний чинник росту [55].

Відомо, що концентрація L-аргініну значно знижується в жінок із гестаційною гіпертензією або прееклампсією [56]. Також у них значно знижено рівні циркулюючого NO. Відзначено, що у вагітних із прееклампсією збільшуються рівні супероксиду, який швидко реагує з NO, що призводить до значного скорочення пулу NO в циркуляції та подальшого підвищення артеріального тиску. Тому збільшення продукування NO з використанням L-аргініну може подолати окислювальні ефекти супероксиду та значно знизити артеріальний тиск [5].

\section{Висновки}

Структура молекули L-аргініну передбачає його участь у великій кількості клітинних процесів. Він знаходиться в активних ділянках багатьох білків. Його структура є сприятливою для зв'язування фосфатного аніону і тому каталізує реакції фосфорилювання. Аргінін відіграє важливу роль у підтримці заряду багатьох білків. Він сприяє детоксикації аміаку, секреції гормонів і бере участь у підтримці імунної системи. Перетворення аргініну на NO сприяє лікуванню різних патологій, таких як серцево-судинні захворювання, захворювання периферичних судин, еректильна дисфункція, атеросклероз, стенокардія, мігрень, шляхом посилення вазодилятації. Аргінін прискорює синтез білків, контролює виснаження тканин у людей із міопатією, а також стимулює продукування сперми. L-аргінін може справляти комплексну дію на тромбоцити, коагуляцію та фібринолітичні системи $[57,58]$. Тому слід враховувати терапевтичний потенціал L-аргініну та продовжувати вивчення можливостей його використання як перспективного профілактичного засобу щодо прогресування судинної дисфункції, пов'язаної зі старінням, діабетом і серцево-судинними захворюваннями. Особливу увагу слід приділити спроможності L-аргініну модулювати системне запалення, що, у свою чергу, може справити позитивний вплив на ендотеліальну функцію судин.

\section{Список використаної літератури}

1. Литвяков АМ, Сергиевич АВ. Аргинин-зависимые механизмы в патогенезе атеросклероза. Весці НАН Беларусі. 2013;1:103-12. (Litvyakov AM, Sergiyevich AV. Arginine-dependent mechanisms in the pathogenesis of atherosclerosis. Vestsi NAN Belarusi. 2013;1:103-12).

2. Morris SM Jr. Recent advances in arginine metabolism: roles and regulation of the arginases. Br J Pharmacol. 2009;157(6):922-30.

3. Morris SM Jr. Arginine metabolism revisited. J Nutr. 2016;146(12):2579S-86S.

4. Heffernan KS, Fahs CA, Ranadive SM, Patvardhan EA. L-arginine 
Лекції

as a nutritional prophylaxis against vascular endothelial dysfunction with aging. J Cardiovasc Pharmacol Ther. 2010;15(1):17-23.

5. McRae MP. Therapeutic benefits of l-Arginine: an umbrella review of meta-analyses. J Chiropr Med. 2016;15(3):184-9.

6. Krause M, Rodrigues-Krause J, O'Hagan C, De Vito G, Boreham C, Susta D, et al. Differential nitric oxide levels in the blood and skeletal muscle of type 2 diabetic subjects may be consequence of adiposity: a preliminary study. Metabolism. 2012;61(11):1528-37.

7. Rodrigues-Krause J, Krause M, Rocha IMGD, Umpierre D, Fayh APT. Association of 1-Arginine supplementation with markers of endothelial function in patients with cardiovascular or metabolic disorders: a systematic review and meta-analysis. Nutrients. 2018:11(1):E15.

8. Michael SK, Surks HK, Wang Y. High blood pressure arising from a defect in vascular function. Proc Natl Acad Sci U S A. 2008; 105(8):6702-7.

9. Farah C, Michel LYM, Balligand JL. Nitric oxide signalling in cardiovascular health and disease. Nat Rev Cardiol. 2018;15(5):292-316

10. Марков ХМ. Молекулярные механизмы дисфункции сосудистого эндотелия. Кардиология. 2005;6:87-95. (Markov KhM. Molecular mechanisms of vascular endothelial dysfunction. Kardiologiya. 2005;6:87-95).

11. Chen M, Yi B, Zhu N, Wei X, Zhang GX, Huang S, et al. Pim1 kinase promotes angiogenesis through phosphorylation of endothelial nitric oxide synthase at Ser633. Cardiovasc Res. 2016;109:141-50.

12. Bibli SI, Zhou Z, Zukunft S, Fisslthaler B, Andreadou I, Szabo C, et al. Tyrosine phosphorylation of eNOS regulates myocardial survival after an ischaemic insult: role of PYK2. Cardiovasc Res. 2017;113:926-37.

13. Heffernan KS, Vieira VJ, Valentine RJ. Microvascular function and ageing L-arginine, tetrahydrobiopterin and the search for the fountain of vascular youth. J Physiol. 2008;586(8):2041-2.

14. Delp MD, Behnke BJ, Spier SA, Wu G, Muller-Delp JM. Ageing diminishes endothelium-dependent vasodilatation and tetrahydrobiopterin content in rat skeletal muscle arterioles. J Physiol. 2008;586(4):1161-8.

15. Durante W, Johnson FK, Johnson RA. Arginase: a critical regulator of nitric oxide synthesis and vascular function. Clin Exp Pharmacol Physiol. 2007;34(9): 906-11.

16. Kovzun EI, Lukashenia OS, Pushkarev VM, Mikosha AS, Tronko MD. Effect of ions of potassium and lithium on NO synthase expression in the human adrenal cortex. Bull Exp Biol Med. 2014;156(3):332-4.

17. Stojiljkovic M, Zakula Z, Koricanac G, Milosavljevic T, Tepavcevic S, Sudar E, et al. Regulation of cardiac nitric oxide synthase in acute type i diabetes: modulation of L-arginine availability and arginase activity. Adv Sci Lett. 2012;5(20);566-74.

18. Sudar-Milovanovic E, Obradovic M, Jovanovic A, Zaric B, Zafirovic S, Panic A, et al. Benefits of L-arginine on cardiovascular system. Mini Rev Med Chem. 2016;16(2):94-103.

19. Dobutovic B, Smiljanic K, Soskic S, Düngen H-D, Isenovic ER. Nitric oxide and its role in cardiovascular diseases. The Open Nitric Oxide J. 2011;3:65-71.

20. Flammer AJ, Luscher TF. Three decades of endothelium research: from the detection of nitric oxide to the everyday implementation of endothelial function measurements in cardiovascular diseases. Swiss Med Wkly, 2010;140:w13122.

21. Bode-Boger SM, Scalera F, Ignarro LJ. The L-arginine paradox: importance of the L-arginine/asymmetrical dimethylarginine ratio. Pharmacol Ther. 2007;114(3):295-306.

22. Boger RH. The pharmacodynamics of L-arginine. J Nutr. 2007;137(6 Suppl 2):1650S-5S.

23. Pretnar-Oblak J. Cerebral endothelial function determined by cerebrovascular reactivity to L-arginine. Biomed Res Int. 2014;2014:601515.

24. Karlsson WK, Sørensen CG, Kruuse C. L-arginine and l-NMMA for assessing cerebral endothelial dysfunction in ischaemic cerebrovascular disease: A systematic review. Clin Exp Pharmacol Physiol. 2017;44(1):13-20.

25. Czarnecka A, Aleksandrowicz M, Jasiński K, Jaźwiec R, Kalita K, Hilgier W, et al. Cerebrovascular reactivity and cerebral perfusion of rats with acute liver failure: role of L-glutamine and asymmetric dimethylarginine in L-arginine-induced response. J Neurochem. 2018;147(5):692-704.
26. Andresen J, Shafi NI, Bryan RM Jr. Endothelial influences on cerebrovascular tone. J Appl Physiol. 2006;100(1):318-27.

27. Ramchandra R, Hood SG, May CN. Central exogenous nitric oxide decreases cardiac sympathetic drive and improves baroreflex control of heart rate in ovine heart failure. Am J Physiol Regul Integr Comp Physiol. 2014;307:R271-80.

28. Rajapakse NW, Head GA, Kaye DM. Say NO to obesity-related hypertension: role of the L-arginine-nitric oxide pathway. Hypertension. 2016;67(5):813-9.

29. Biancardi VC, Son SJ, Sonner PM, Zheng H, Patel KP, Stern JE. Contribution of central nervous system endothelial nitric oxide synthase to neurohumoral activation in heart failure rats. Hypertension. 2011;58:454-63.

30. Chen YC, Liu YC, Yen DH, Wang LM, Huang CI, Lee CH, et al. L-arginine causes amelioration of cerebrovascular dysfunction and brain inflammation during experimental heatstroke. Shock. 2008;29(2):212-6.

31. Hu S, Han M, Rezaei A, Li D, Wu G, Ma X. L-arginine modulates glucose and lipid metabolism in obesity and diabetes. Curr Protein Pept Sci. 2017;18(6):599-608.

32. Mittermayer F, Kautzky-Willer A, Winzer C, Krzyznowska K, Prikoszovich T, Demehri S, et al. Elevated concentrations of asymmetric dimethylarginine are associated with deterioration of glucose tolerance in women with previous gestational diabetes mellitus. I Intern Med. 2007;261:392-8.

33. Das UN, Repossi G, Dain A, Eynard AR. L-arginine, NO and asymmetrical dimethylarginine in hypertension and type 2 diabetes. Front Biosci (Landmark Ed). 2011 1;16:13-20.

34. Borucki K, Aronica S, Starke I, Luley C, Westphal S. Addition of $2.5 \mathrm{~g} 1$-arginine in a fatty meal prevents the lipemia-induced endothelial dysfunction in healthy volunteers. Atherosclerosis. 2009;205(1):251-4.

35. Dubó S, Gallegos D, Cabrera L, Sobrevia L, Zúñiga L, González M. Cardiovascular action of insulin in health and disease: endothelial L-Arginine transport and cardiac voltage-dependent potassium channels. Front Physiol. 2016;7:74.

36. Hoang HH, Padgham SV, Meininger CJ. L-arginine, tetrahydrobiopterin, nitric oxide and diabetes. Curr Opin Clin Nutr Metab Care. 2013;16(1):76-82.

37. Monti LD, Setola E, Lucotti PCG, Marrocco-Trischitta MM, Comola M, Galluccio E, et al. Effect of a long-term oral L-arginine supplementation on glucose metabolism: a randomized, double-blind, placebo-controlled trial. Diabetes Obes Metab. 2012;14:893-900.

38. Dhar I, Dhar A, Wu L, Desai K. Arginine attenuates methylglyoxaland high glucose-induced endothelial dysfunction and oxidative stress by an endothelial nitric oxide synthase-independent mechanism. J Pharmacol Exp Therapeut. 2012;342:196-204.

39. Assumpção CR, Brunini TM, Pereira NR, Godoy-Matos AF, Siqueira MA, Mann GE, et al. Insulin resistance in obesity and metabolic syndrome: is there a connection with platelet l-arginine transport? Blood Cells Mol Dis. 2010;45:338-42.

40. Rajapakse NW, Karim F, Straznicky NE, Fernandez S, Evans RG, Head GA, et al. Augmented endothelial-specific L-arginine transport prevents obesity-induced hypertension. Acta Physiol (Oxf). 2014;212:39-48.

41. Ettehad D, Emdin CA, Kiran A, Anderson SG, Callender T, Emberson J, et al. Blood pressure lowering for prevention of cardiovascular disease and death: a systematic review and metaanalysis. Lancet. 2016;387(10022):957-67.

42. da Cunha NV, Pinge-Filho P, Panis C, Silva BR, Pernomian L, Grando MD, et al. Decreased endothelial nitric oxide, systemic oxidative stress, and increased sympathetic modulation contribute to hypertension in obese rats. Am J Physiol Heart Circ Physiol. 2014;306: H1472-80.

43. Hall JE, do Carmo JM, da Silva AA, Wang Z, Hall ME. Obesityinduced hypertension: interaction of neurohumoral and renal mechanisms. Circ Res. 2015;116:991-1006.

44. Rondón LJ, Farges MC, Davin N, Sion B, Privat AM, Vasson MP, et al. L-Arginine supplementation prevents allodynia and hyperalgesia in painful diabetic neuropathic rats by normalizing plasma nitric oxide concentration and increasing plasma agmatine concentration. Eur J Nutr. 2018;57(7):2353-63. doi: 10.1007/ s00394-017-1508-x. 
45. Head KA. Peripheral neuropathy: pathogenic mechanisms and alternative therapies. Altern Med Rev. 2006 Dec;11(4):294-329.

46. El-Lithy GM, El-Bakly WM, Matboli M, Abd-Alkhalek HA, Masoud SI, Hamza M. Prophylactic L-arginine and ibuprofen delay the development of tactile allodynia and suppress spinal miR-155 in a rat model of diabetic neuropathy. Transl Res. 2016;177:85-97. e1. doi: 10.1016/j.trsl.2016.06.005.

47. Deanfield JE, Halcox JP, Rabelink TJ. Endothelial function and dysfunction: testing and clinical relevance. Circulation. 2007;115(10):1285-95.

48. Godo S, Shimokawa H. Endothelial functions. Arterioscler Thromb Vasc Biol. 2017;37(9):e108-14.

49. Cylwik D, Mogielnicki A, Buczko W. L-arginine and cardiovascular system. Pharmacol Rep. 2005;57(1):14-22.

50. Gambaryan S, Tsikas D. A review and discussion of platelet nitric oxide and nitric oxide synthase: do blood platelets produce nitric oxide from L-arginine or nitrite? Amino Acids. 2015;47(9):1779-93.

51. Tan B, Li X, Yin Y, Wu Z, Liu C, Tekwe CD, et al. Regulatory roles for L-arginine in reducing white adipose tissue. Front Biosci (Landmark Ed). 2012;17:2237-46.

52. Popovic PJ, Zeh HJ 3rd, Ochoa JB. Arginine and immunity. J Nutr. 2007;137(6, Suppl 2):1681S-6S.

53. Szefel J, Danielak A, Kruszewski WJ. Metabolic pathways of $\mathrm{L}$-arginine and therapeutic consequences in tumors. Adv Med Sci. 2019;64(1):104-10.

54. Stechmiller JK, Childress B, Cowan L. Arginine supplementation and wound healing. Nutr Clin Pract. 2005;20(1):52-61.

55. Zuchi C, Ambrosio G, Lüscher TF, Landmesser U. Nutraceuticals in cardiovascular prevention: lessons from studies on endothelial function. Cardiovasc Ther. 2010;28(4):187-201.

56. López-Jaramillo P, Arenas WD, García RG, Rincon MY, López M. The role of the L-arginine-nitric oxide pathway in preeclampsia. Ther Adv Cardiovasc Dis. 2008;2(4):261-75.

57. Fuhrmann J, Schmidt A, Spiess S, Lehner A, Turgay K, Mechtler K, et al. McsB is a protein arginine kinase that phosphorylates and inhibits the heat-shock regulator CtsR. Science. 2009;324:1323-7.

58. Verma N, Singh AK, Singh M. L-arginine biosensors: A comprehensive review. Biochem Biophys Rep. 2017;12:228-39.

(Надійшла до редакції 08.11.2019р.)

\section{L-аргинин в норме и патологии}

\section{Л.К. Соколова, В.М. Пушкарев, Н.Д. Тронько}

ГУ «Институт эндокринологии и обмена веществ им. В.П. Комиссаренко НАМН Украины»

Резюме. L-аргинин - условно незаменимая аминокислота, являющаяся клеточным регулятором многих жизненно важных функций организма. Он участвует в регуляции тонуса гладкомышечного компонента стенки сосудов, бронхов, кишечника. L-аргинин является субстратом для синтазы оксида азота (NOS), которая продуцирует оксид азота (NO). NO, продуцируемый в эндотелии сосудов, отвечает за релаксацию гладких мышц и необходим для снижения артериального давления. L-аргинин имеет высокий функциональный приоритет в продукции NO и, следовательно, в физиологии сердечно-сосудистой и цереброваскулярной систем. L-аргинин может уменьшать ожирение, снижать артериальное давление, подавлять окислительные процессы и нормализовать эндотелиальную дисфункцию, способствуя ремиссии при диабете 2-го типа. L-аргинин также используется клетками иммунной системы, может снижать уровень инфицирования, особенно при нарушении иммунной функции. L-аргинин замедляет старение, ингибирует агрегацию тромбоцитов, регулирует множественные метаболические пути, связанные с метаболизмом жирных кислот, глюкозы, аминокислот и белков. Поэтому следует учитывать большой терапевтический потенциал L-аргинина и продолжать изучение возможностей его использования в качестве перспективного препарата при прогрессировании сосудистой дисфункции, связанной со старением, диабетом и сердечно-сосудистыми заболеваниями.

Ключевые слова: L-аргинин, оксид азота, диабет, сердечно-сосудистая система, ожирение, цереброваскулярная система, иммунная система, агрегация тромбоцитов.

\section{L-arginine in norm and pathology}

\section{L.K. Sokolova, V.M. Pushkarev, M.D. Tronko}

SI «V.P. Komisarenko Institute of endocrinology and metabolism of NAMS of Ukraine», Kyiv

Abstract. L-arginine is a conditionally essential amino acid, which is the cellular regulator of many vital functions of the body. He is involved in the regulation of the tone of the smooth muscle component of the blood vessels wall, bronchi, and intestines. L-arginine is a substrate for the nitric oxide synthase (NOS), which produces nitric oxide (NO). NO, produced in the vascular endothelium of endothelial NOS, is responsible for the relaxation of smooth muscles and is necessary to lower blood pressure. L-arginine has a high functional priority in the production of NO and, therefore, in the physiology of the cardiovascular and cerebrovascular systems. L-arginine can reduce obesity, lower blood pressure, suppress oxidative processes and normalize endothelial dysfunction, contributing to remission in type 2 diabetes. Larginine is also used by cells of the immune system, can reduce the level of infection, especially in case of impaired immune function. L-arginine slows down aging, inhibits platelet aggregation, and regulates multiple metabolic pathways associated with the metabolism of fatty acids, glucose, amino acids and proteins. Therefore, one should take into account the great therapeutic potential of L-arginine and continue to study the possibilities of its use as a promising drug against the progression of vascular dysfunction associated with aging, diabetes and cardiovascular diseases.

Keywords: L-arginine, nitric oxide, diabetes, cardiovascular system, obesity, cerebrovascular system, immune system, platelet aggregation. 